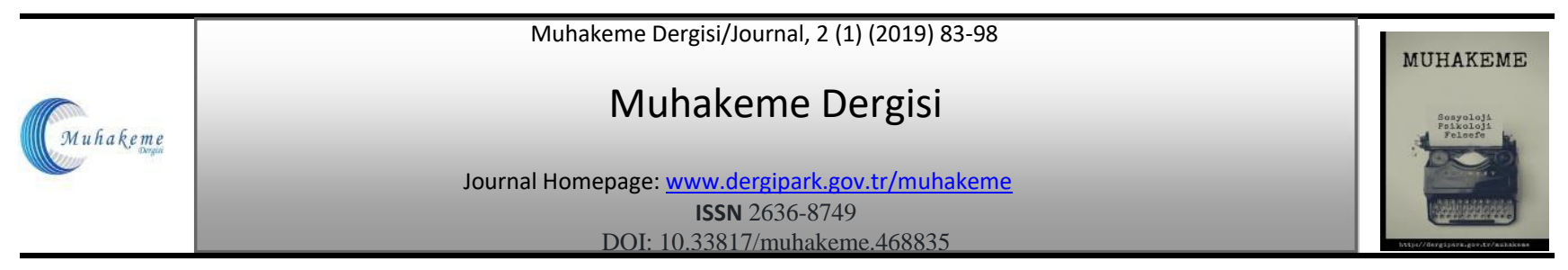

\title{
Sosyolojik Açıdan Sporda Şiddet Olgusu: Bütüncül Bir Bakış
}

Metin KILIÇ ${ }^{1}$

\section{ÖZET}

Spor insanların birçok kurumsal yapıya göre daha esnek hareket etme firsatı bulduğu bir alandır. Bireysel ve toplumsal manada sporun hayatı kuşattı̆̆ı, sosyal münasebetlerin yeniden üretiminde etkili olduğunu söylemek pekte yanlış olmaz. Sporun doğası gereği, insanların karakter gelişimine, sosyalleşmesine ve olumsuz davranışlardan uzaklaşmasına imkân sağlaması gerekirken, şiddet olayları da toplumsal yaşamda en çok spor alanlarında gözlenmektedir. Bu açıdan birbirine zıt olan bu iki kavram üzerine birçok bilimsel inceleme yapılmıştır. Yapılan incelemelerde yoğun olarak sporda fiziksel şiddet, taraftar şiddeti, saldırganlık, fanatizm gibi konular tespit edilmeye ve çözümlenmeye çalışılmıştır. Sporda şiddet olgusu bütüncül bir açıdan (fiziksel, psikolojik, ekonomik, cinsel şiddet) derinlemesine araştırılmamıştır.

Bu çalışmada 15 farklı spor branşında 14 erkek, 14 kadın olmak üzere toplamda 28 elit sporcuyla mülakat yapılmıştır. Mülakatlar 5 farklı ilde (İstanbul, Kocaeli, Sakarya, Düzce ve Bolu) sporculara uygulanmıştır. Tematik veri analizi yöntemine göre elde edilen verilerden, sporcuların fiziksel, psikolojik, ekonomik ve cinsel şiddetin farklı boyutlarına antrenör, seyirci ve sporcu üçlemesinde nasıl maruz kalabildikleri sporcuların deneyimleri neticesinde tespit edilmiştir. Ayrıca araştırma sonuçlarına göre sporda ekonomik ve cinsel şiddetinde de yoğun olarak yaşandığı ortaya konulmuştur.

Anahtar Kelimeler: spor sosyolojisi, şiddet, bireysel sporlar, takım sporları, cinsiyet

\section{Fact of Violence in Sports from Sociological Perspective: A Holistic View}

\begin{abstract}
Sports is an area where people have the opportunity to move more flexibly than many institutional structures. It would not be wrong to say that sport encompasses life in an individual and social sense and it is effective in the reproduction of social relations. While the nature of sport should allow people to develop their character, socialize and move away from negative behaviors, violence is also observed in most sports areas. In this respect, many scientific studies have been done on these two concepts, sports and violence, which are opposite to each other. In the scientific investigations, issues such as physical violence, fan violence, aggression, and fanaticism have been tried to be assessed and analyzed. The fact of violence in sports has not been investigated in depth from a holistic perspective including physical, psychological, economic, and sexual violence.

In this study, a total of 28 elite athletes, 14 male and 14 female, were interviewed in 15 different sports branches. Interviews have been conducted with athletes in 5 different cities (Istanbul, Kocaeli, Sakarya, Duzce, and Bolu). Data were analyzed using the thematic data analysis method. Based on the experiences of athletes, it has been determined how they can be exposed to different dimensions of physical, psychological, economic, and sexual violence by coach, spectators, and athletes. In addition, findings showed that there is an intensive economic and sexual violence in sports.
\end{abstract}

Keywords: sports sociology, violance, individual sports, team sports, gender

\footnotetext{
${ }^{1}$ Doç. Dr., Düzce Üniversitesi, Fen-Edebiyat Fakültesi, Sosyoloji bölümü, metinkilic@duzce.edu.tr
} 


\section{GİRIŞ}

İnsanlık tarihi kadar eski olan şiddet olgusu üzerine sosyolojinin yanı sıra diğer disiplinlerinde dâhil edildiği geniş bir literatürün olduğu bilinen bir gerçektir. Modernleşmeyle birlikte şiddetin azalması beklenirken değişik şekillerde ve çeşitlilikle şiddetin artması söz konusudur (Kılıç, 2014). Şiddetin neliği ve niteliği sorgulandığında evrensel tanımlamaları söz konusuyken, aynı dönemlerde toplumdan topluma değişiklik gösteren bir olgu olduğu gözden kaçırılmamalıdır. Bu durum bir toplumun toplumsal yapısıyla, kültürel değer yargılarıyla yakından ilgilidir. Değer yargılarına bağlı olarak şiddet pratiklerinin ev içerisinde (Aktaş, 2005; Akkaş ve Uyanık, 2016; Ayan, 2007; Kocadaş ve Kılıç, 2012), okulda (Ögülmüş, 2006; Tekin ve Kılıç, 2010), iş yerinde (Aydın ve Özkul, 2007), medyada (Freedman, 2002; Tosyal1, 2018), sporda (Elias, 1976, Dunning at all, 1991), k1sacası özel ve kamusal yaşamın her alanında gözlemlenmesi söz konusudur. Bu haliyle şiddet tanımlanması oldukça zor olan kavramlardan biridir (Kılıç, 2016).

Etimolojik olarak, kaba kuvvet, sert ve katı davranış, müsaadesizlik, sertlik gibi anlamlara gelen şiddet (Ünsal, 1996), içinde fazladan keyfilik öğesi taşır (Arendt, 2016). Keyfiliği oluşturan tartışma meşrulukla ilgilidir. Şiddet, meşru olmayan baskı; daha doğrusu, meşru görülmeyen baskı olarak tanımlanabilir (Bauman, 2011). Doğası gereği meşru görülmeyen baskı, içinde saldırganlık ve öfke duygusunu barındırır. Tarihsel olarak bilim camiası saldırganlık ve öfke duygusunun temellerini biyolojik ve sosyal nedenlerle açıklamaya çalışmıştır. Kimilerine göre şiddetin temelindeki saldırganlık duygusu biyolojik, genetik nedenlerle açıklanabilirken (Fromm, 1981), kimilerine göre ise sosyal nedenler ve çevre şartları (Bandura and Walters, 1978; Bandura, 1982; Hogg, and Vaughan, 2011; Kocacık, 2001) bu duygunun şekillenmesinde temel etken olmuştur. Günümüzde ise saldırganlığın temellerinde her iki yaklaşımında etken olduğu genel geçer bir kanı olarak kabul edilmektedir. Nedenselliği göz önünde bulundurulduğunda bile çok yönlü olarak karşımıza çıkan şiddetin sosyolojik olarak fiziksel, psikolojik, ekonomik ve cinsel açıdan sınıflandırılması yapılabilir. Bu sınıflandırma karşı karşıya kalınan şiddet davranışının daha kolay çözümlenmesinde etkilidir. Sporda şiddet olgusunu incelerken de bu dört şiddet sınıflandırmasından hareketle, yaptığımız araştırmada sporda şiddetin analiz edilmesi hedeflenmektedir.

\section{Sporda Şiddet ve Sınıflandırılması}

Günümüzde spor çeşitli grupların aralarındaki ilişkileri aktif bir şekilde uyguladığı ve değişen sosyal durumları bütün olarak karşıladıkları bir arenaya dönüştürülmüştür (Jarvie, 2005). Araştırmacıların birçoğu, sportif katılımın insanlar için olumsuz davranışlardan uzaklaşma, karakter gelişimi, çok sayıda imkân ve seçenek sağlayabileceğinden, sporun insanlar arasında köprü kurma, sosyalleştirme potansiyeli olduğu fikrinde hemfikirlerdir (Robins, 1990; Washington and Karen, 2001; Malmisur and Schempp, 2004; Rudd, 2005; Dumitriu, 2012; Kılıç, 2013; Kılıç ve Aslan, 2016; Kılıç ve Arslan, 2018).

Elit spora nazaran kitle sporu ${ }^{2}$ bağlamında (aktif katılım söz konusu olduğunda) düşünüldüğünde araştırmacıların belirttikleri hususlarda sporun kaynaştırıcı etkisinden daha fazla söz etmek mümkündür. Elit sporda ise, bütünleşme ve çatışma zitlı̆̆ yoğun olarak görülmektedir. Ulusal ve uluslararası arenalarda sporun grup dinamiğini ve toplumsal dayanışmayı arttıran (ötekine karşı) bir etkinlik alanı olarak görülmesi söz konusu iken, şiddetin yoğun olarak yaşandığı bir alan olarak da karşımıza çıkmaktadır (Kılıç, 2018). Toplumsal yaşamda spor olgusu bireyselliğin ötesinde taraftar olma (grup dinamiği) mantığıyla kitleleri ilgilendiren bir etkinlik alanı olarak görüldüğünden, sporda şiddet toplumsal alanda karşılaşılan diğer şiddet türlerine oranla daha fazla ön plana çıkmaktadır. Bütün toplumlarda sporda şiddet olgusu evrensel olarak taraftarlar arasında şiddet, taraftarların sporcuya yönelik şiddeti, sporcunun taraftara yönelik şiddeti, sporcu-sporcu arasında şiddet, sporcuteknik ekip arasında, sporcu-hakem arasında ve spor medyasında nefret söylemleri diye

\footnotetext{
${ }^{2}$ Kitle sporu: toplumda yaşam kalitesini arttırmak için her yaş ve cinsiyetteki gruplardan meydana gelen organize spor kulüplerinden, organize olmamış informel serbest zaman gruplarına kadar yapılan kitle sporu, insanın günlük hayatta yeni ve fazla rastlanmayan yaşantılar yoluyla kendisini bulma arzusuna dayanır. Kitle sporu, eğlenmek, zevk almak, hoşça vakit geçirmek, sosyalleşmek ve sağlıklı olmak amacıyla yapılmaktadır. Elit Spor: belirli kurallar çerçevesinde, belirli yaşlarda ve yeterli düzeyde yeteneğe sahip olanların statü ve para kazanmak için belirli bir mesai kavramına bağlı olarak yaptıkları iştir (Kılıç, 2018).
} 
sınıflandırılması söz konusudur. Bu sınıflandırmaya kaynaklık eden yaş, cinsiyet, etnik kimlik, medya, gibi sosyolojik kategoriler bulunmaktadır. Bu nedenle, Jarvie'nin (2012) söyleminden hareketle "sporda şiddet ve nasıl azaltılabileceği veya engellenebileceği spor, kültür ve toplum alanı dâhilinde cevaplandırılması en zor sorulardan biridir". Toplumdaki sporda şiddet farklı şiddet biçimleri şiddet oranları ve birçok araştırmaya sebep olan sapkınlık ve şiddetle ilgili olarak sporu içeren çeşitlendirilmiş çözümler de bulunmaktadır. Literatürde, taraftar şiddeti ve sporcu şiddetinin fiziksel ve psikolojik şiddet türlerinde ön plana çıktığını söyleyebiliriz. Türkiye'de sporda şiddet üzerine yapılan birçok çalışmada da saldırganlık, taraftarlık, fanatiklik konuları çözümlenmeye çalışılmış (Ayan, 2006; Afyon ve Metin, 2014; Koçer, 2012; Türkmen ve diğ., 2013; Yücel ve diğ., 2015; Polat ve Sönmezoğlu, 2016), spor medyasının da sporda şiddeti nasıl ürettiği araştırılmıştır (Demir, 2009; Özsoy, 2011; Özsoy ve Yıldız, 2013; Mil ve Şanlı, 2015; Kılıç, 2015a). Yapılan çalışmalarda sporda şiddet olgusu; fiziksel, psikolojik, ekonomik ve cinsel şiddet boyutlarında derinlemesine bütüncül bir bakış açısıyla ortaya konulmamıştır.

\section{Sporda Fiziksel Şiddet}

Fiziksel şiddet toplumsal yaşamda ve sporda şiddetin en sık ve görünür şekli olarak karşımıza çıkmaktadır. Fiziksel şiddet daha çok bedene yöneliktir ve bedensel güce dayalıdır. Müsabaka esnasında sporcuların birbirlerine vurma, tekme atma, tükürme, yumruklama, yaralama gibi eylemler içerisine girmesi fiziksel şiddet olarak tanımlanır. Sporda fiziksel şiddetin nesnelere yönelik olarak da ortaya çıkması söz konusudur. Futbolcunun kale duvarlarını veya çimleri tekmelemesi, tenisçinin raketini yere vurarak parçalaması yine sporda fiziksel şiddettir. Sporda fiziksel şiddet sadece sporcular arasında gözlemlenen fair-play dışı davranışta değildir. Sporcu tarafından hakeme ya da hakem tarafindan sporculara, seyirci tarafindan sporculara, hakeme, seyircilere benzer eylemlerde bulunmakta sporda fiziksel şiddet olarak tasnif edilir. Seyircilerin oyunculara ya da hakeme pet şişe, bozuk para atmaları, sporda fiziksel şiddete örnektir.

\section{Sporda Psikolojik Şiddet}

Spor alanlarında fiziksel şiddet kadar yoğun olarak gözlemlenen diğer bir şiddet türü de psikolojik şiddettir. Psikolojik şiddet, fiziksel şiddetten bağımsız olarak gerçekleşse dahi her zaman fiziksel şiddete ya da diğer bir şiddete dönüşme tehlikesini içinde barındırmaktadır. Sporda psikolojik şiddet; sporcunun, seyircinin, antrenörün rakibe, kendi takımının oyuncularına ya da hakeme küfür etmesi, bağırması, hakaret etmesi, onu aşağılaması, jest ve mimiklerle eleştirmesi şeklinde ortaya çıkabileceği gibi, müsabaka dışında da gerçekleşebilir. Antrenmanlarda ya da müsabaka arasında antrenörün kişiyi aşağılayıcı söylemlerde bulunması, aktif spor müsabakasına katılmasına firsat vermemesi ve yedek oynatması da psikolojik şiddet olarak karşımıza çıkmaktadır. Sporda psikolojik şiddetin rutin olarak tekrarlanıp sıradanlaşması neticesinde yeterince anlamlandırılmaması söz konusudur. Spor müsabakalarında taraftar gruplarının birbirlerine, sporculara ya da hakeme yönelik aşağılayıcı, alaylı ve küfür içerikli söylemlerinin sıradanlaşması sporda psikolojik şiddetin normalleştirilmesine sebebiyet vermektedir.

\section{Sporda Ekonomik Şiddet}

Sporda ekonomik şiddet; ekonomik kaynakların ve paranın sporcular üzerinde bir yaptırım, iktidar ve tehdit aracı olarak kullanılmasıdır. Elit spor bağlamında, sporcuların çalışma yaşamında ilerlemesine engel olma, maaşına, gelirine el koyma, az para verme, priminden kesme, prim sözü verip-prim vermeme, çok az para verip yapılması mümkün olmayan şeyleri talep etme, yedek oynatma, kadroya almama, sağlık hizmetlerinden yararlanmasını engelleme gibi söylem ve eylemlerle karşımıza çıkmaktadır. Diğer şiddet türleri ile bağlantı içerisinde olan ekonomik şiddet olgusu, sporcuların yaşam kalitesini, performansını ve motivasyonunu etkileyen olumsuz bir faktördür. Sporun meslek olarak yapıldığı ve mesai gerektirdiği göz önünde bulundurulduğunda, sporcuların motivasyonuna olumsuz etki edecek temel unsur kuşkusuz ekonomik anlamdaki engelle(n)melerdir. 


\section{Sporda Cinsel Şiddet}

Cinsel şiddet yakın döneme kadar fiziksel şiddetin bir uzantısı olarak ele alınmaktaydı. Bunun nedeni ise çoğunlukla somut olarak gözlenebilmesi ve fiziksel bir eyleme bağlı olarak gerçekleşmesinin göz önünde bulundurulmasıdır. Ama günümüzde cinsel şiddetin sadece fiziksel bir eylem olarak düşünülmesi söz konusu değildir. Bu açıdan psikolojik şiddetle de çok yakın ilişkinin kurulması söz konusudur. Kişinin bir cinsel obje olarak görülmesi, gözle ya da sözle taciz edilmesi gibi durumlarda cinsel şiddet olarak değerlendirilmektedir (Kılıç, 2017).

Sporda fiziksel açıdan cinsel şiddet, sporcunun isteği gözetilmeksizin cinselliğin bir zorlama ve kısıtlama aracı olarak kullanımıdır. Tecavüz, sporcunun fiziksel veya duygusal baskıyla cinselliğe zorlanması, cinsellikte tamamen bir obje olarak kullanılması ve cinsel taciz bu şiddet türünün yansımalarıdır. Sporda cinsel şiddet olgusunu daha da netleştirmek gerekirse; seyircinin sporcunun belli cinsel bölgelerine odaklanması, fiziksel temas gerektiren sporlarda ya da antrenmanlarda antrenör sporcu arasında spor ahlakına aykırı eylemlerde bulunulması ve bu durumun meşrulaştırılması için sporcunun kariyeri üzerine tahakküm kurulması, sporla ilgili olmayan reklamlarda ya da programlarda sporcuların bir meta olarak kullanılması, kameraların sporcuların cinsel bölgelerine odaklanması gibi durumların birçoğu sporda cinsel şiddet unsuru olarak ele alınmalıdır.

\section{YÖNTEM}

\section{Araştırmanın Amacı ve Önemi}

Sporda şiddet olgusu üzerine uluslararası ve ulusal alan yazında çok fazla çalışma bulunmaktadır. Yapılan çalışmalar çoğunlukla fanatizm, holiganizm ve fiziksel şiddet alanlarında toplanmaktadır. Yaptığımız araştırmada elit sporcuların gözünden sporda şiddet olgusu değerlendirilmeye çalışılmıştır. Bu kapsamda sporcuların gözünden şiddetin nasıl anlamlandırıldığı takım ve bireysel spor branşlarında farklı şiddet unsurlarını nasıl gözlemledikleri analiz edilmeye çalışılmıştır.

\section{Örneklem}

Araştırmanın örneklemini 20-35 yaş aralığında bulunan 28 elit sporcu oluşturmaktadır. 15 farklı spor branşında (Basketbol, Boks, Yüzme, Voleybol, Muay Thai, Atletizm, Judo, Hentbol, Güreş, Karete, Yelken, Tekvando, Eskrim, Futbol, Wushu Sandu) aktif olarak sporla uğraşan 14 kadın ve 14 erkek sporcuyla İstanbul (12 Sporcu), Kocaeli (4 sporcu), Sakarya (6 sporcu), Düzce (4 sporcu) ve Bolu'da (2 sporcu) görüşmeler yapılmıştır.

\section{Araştırmanın Modeli}

Araştırmada sporculardan derinlemesine bilgi almak ve kendilerini nasıl ifade ettiklerini anlamlandırmak için nitel araştırma yöntemlerinden biri olan görüşme (mülakat) tekniği kullanılmıştır. Araştırmanın amacı doğrultusunda sorulan sorulara ilişkin detaylı bilgiye sahip olabilmek adına yarı-yapılandırılmış görüşmeler yapılmıştır.

Araştırma doğrultusunda yapılan görüşmelerde sorular fiziksel, psikolojik, ekonomik ve cinsel şiddet türlerinin sporcular üzerindeki etkisini ortaya koyabilecek temalara odaklanmıştır. Görüşme soruları araştırmacı tarafından ilgili literatür taraması yapılarak hazırlanmışıı. Soruların içeriğini sporcuların yaşam öyküleri, spora yönelme sebepleri, şiddet ve şiddet türlerinin toplumsal alanda ve spor alanında etkileri hakkındaki görüşleri oluşturmaktadır. Bu bağlamda "Sporda Fiziksel Şiddetin Anlamlandırılması", Sporda Psikolojik Şiddetin Anlamlandırılması", "Sporda Ekonomik Şiddetin Anlamlandırılması" ve "Sporda Cinsel Şiddetin Anlamlandırılması" şeklinde dört ana tema belirlenmiştir.

\section{Verilerin Toplanması ve Analizi}

Öncelikli olarak araştırmanın yapılması için sporcuların antrenmanları sürecinde, yöneticilerinden gerekli izinler alınmıştır. Alınan izinlerden sonra 05-22 Şubat 2018 tarihleri arasında İstanbul'da, 05-09 Mart 2018 tarihleri arasında Kocaeli'nde, 19-23 Mart 2018 tarihleri arasında Sakarya'da, 02 Nisan 2018 tarihinde Bolu'da ve 16-20 Nisan tarihleri arasında Düzce'de sporcularla toplamda 42 saat süren görüşmelerde derinlemesine ve ayrıntılı bilgiler elde edilmiştir. Araştırma esnasında sporculara herhangi bir zorlama yapılmamış ve araştırma gönüllülük esaslarına dayanılarak samimi bir ortamda gerçekleştirilmiştir. Uygulama esnasında görüşme yapılan ortam, sporcuların psikolojik durumlarını olumsuz etkileyecek 1S1, 1şı̂, ses gibi olumsuzluğa sebebiyet verecek unsurlardan arındırılmıştır.

Görüşmeler ASUS marka dijital ses kayıt cihazı ile kayıt altına alınmıştır. Görüşmelerden elde edilen kayıtlar, görüşmeleri takip eden günlerde ses dosyaları olarak bilgisayara aktarılmış ve konuşmalar araştırmacı tarafından 
defaten dinlenerek analiz edilmiştir. Analiz sürecinde konuşmalar ses kayıt cihazından bilgisayarda Word metinlerine dönüştürülmüştür. Örneklemin deşifre edilmemesi için isimleri kullanılmaktan kaçınılmış ve kişileri tanımlayıcı kodlar (Tablo 1 de) verilmiştir.

Araştırmada verileri "sistematik olarak tanımlama, organize etme ve veri topluluğu üzerinden tema örüntüsüne ilişkin bir anlam sunma yöntemi” olarak tanımlanmış olan “Tematik Veri Analizi” yöntemi kullanılmıştır (Braun ve Clarke 2006).

\section{Araştırma Bulguları}

Tablo: 1 Örneklemi Tanımlayıcı Bazı Özellikler

\begin{tabular}{|l|l|l|l|}
\hline Örneklem & Cinsiyet & Yaş & \multicolumn{1}{|c|}{ Branşs } \\
\hline K1 & KADIN & 25 & Boks \\
\hline K2 & KADIN & 22 & Yüzme \\
\hline K3 & KADIN & 22 & Voleybol \\
\hline K4 & KADIN & 20 & Yüzme \\
\hline K5 & KADIN & 24 & Voleybol \\
\hline K6 & KADIN & 21 & Voleybol \\
\hline K7 & KADIN & 21 & Muay Thai \\
\hline K8 & KADIN & 27 & Boks \\
\hline K9 & KADIN & 26 & Atletizm \\
\hline K10 & KADIN & 22 & Basketbol \\
\hline K11 & KADIN & 23 & Judo \\
\hline K12 & KADIN & 24 & Voleybol \\
\hline K13 & KADIN & 22 & Hentbol \\
\hline K14 & KADIN & 24 & Güres \\
\hline E1 & ERKEK & 26 & Karate \\
\hline E2 & ERKEK & 35 & Yelken \\
\hline E3 & ERKEK & 22 & Tekvando \\
\hline E4 & ERKEK & 24 & Eskrim \\
\hline E5 & ERKEK & 23 & Wushu Sondu \\
\hline E6 & ERKEK & 22 & Güres \\
\hline E7 & ERKEK & 25 & Futbol \\
\hline E8 & ERKEK & 25 & Voleybol \\
\hline E9 & ERKEK & 21 & Basketbol \\
\hline E10 & ERKEK & 22 & Futbol \\
\hline E11 & ERKEK & 23 & Futbol \\
\hline E12 & ERKEK & 25 & Hentbol \\
\hline E13 & ERKEK & 24 & Hentbol \\
\hline E14 & ERKEK & 23 & \\
\hline & & & 25 \\
\hline
\end{tabular}

\section{Tema 1: Sporda Fiziksel Şiddetin Anlamlandırılması}

Günümüzde sporda şiddet araştırmalarından hareketle fiziksel şiddetin kitlesel sporlarda (futbol, basketbol vb) daha fazla gözlenmesi söz konusuyken, spor kültürü ve olimpik ruhun yerleşmediği toplumların tümünde branş ayırımı gözetmeksizin fiziksel şiddetten söz etmek mümkündür. Yapılan araştırmada farklı branşlara mensup sporcuların toplumsal cinsiyet ayırımı gözetildiğinde bile fiziksel şiddete maruz kalması bunun en açık kanıtıdır. Toplumsal yapı içerisinde özel ve kamusal alanlar fark etmeksizin her tür şiddetin hukuki müeyyidesi olduğu vatandaşlar tarafından bilinirken, spor alanları 
söz konusu olduğunda şiddetin daha kolay meşrulaştırılması ve şiddete başvurulması söz konusudur. Sporcular açısından da mücadele de kazanma hırsı, rekabet gibi durumlarda başarma ya da kazanmak pahasına veya kaybetmelerini hazmedememeleri neticesinde fiziksel şiddete başvurdukları gözlenmektedir. Bu durumu bireysel sporlarla uğraşan K8, K12, E3 ve E4 kodlu sporcular şu sözleriyle anlamlandirmaktadir:

"Kendi branşımda kural dışı maçın içerisinde iken galibiyet için maç sırasında kural dışı vuruşların çok olduğunu söyleyebilirim” (K8, 27, Muay Thai). "Maçta yenilen birçok sporcuya şahit oldum selam vermeden kemerini firlatan, su şişelerinin havada uçuştuğu, duvarları yumruklayan birçok olayla karşı karşıya kaldım. Ben öfke kontrolü sağlamakta zorluk çekmiyorum, şunu iyi biliyorum yenilmeden yenmeyi, bir tecrübe kazanmadan kaybetmenin ne demek olduğunu anlamiyorsun” (K12, 24, Judo). "2008 den beri yelken sporuyla elit düzeyde ilgileniyorum. 2012 yllında Avrupa Şampiyonasinda Portekiz Tavira'da lider sıradaydım. Son 2 gün kala yarışın bitmesine rakiplerimin kıskanmasından dolayı Portekizli bir çocuk parmağıma ip kesme bahanesiyle bıçakla kesmişti. Lider olduğum halde yarışı 3. Sirada bitirebildim" (E3, 22, Yelken). "Kendi tekvando branşımda bir Türkiye şampiyonasında ikinci maçımda İzmirli bir rakibimle karşılaştım. Maç benim üstünlüğümle devam ediyordu ve son raunda girmiştik. Son raunt rakiple aramızda 12 sayı fark vardı ve maçı aldım gözüyle bakıyordum. Son raunt rakip yasak olduğu halde sadece alt bölgeye çallşarak beni sakat bıraktı ve kendisi de diskalifiye oldu. Kafaya oynayacağım bir maçta fiziksel şiddete maruz kalarak diğer maçlara devam edemedim" (E4, 24, Tekvando).

Bireysel sporlarda sporcular arasında karşılaşılan fiziksel şiddetin yanında takım sporlarında da benzer olumsuz durumların yoğun olarak yaşandığını, takım sporlarıyla uğraşan sporcuların söylemlerinden çıkarmak mümkündür. Araştırmaya katılan E12, E13, ve E14'ün söylemleri bu durumu destekler niteliktedir.

"Bir futbol maçında sporcular arasında önce sözlü atı̧̧malar olur. Sonrasında birbirlerini iterek, ayaklarına vurarak bu fiziksel eyleme dönüşür. Çok fazla yaşanılır futbolda bu" (E12, 25, Futbol). "Hentbol rakiplere temaslı bir spordur. Tokat, pençe yumruk gibi fiziksel temas çok yașanmaktadır" (E13, 24, Hentbol). "Branșım hentbol olduğu için rakiple gögüs gögüse de sert ve kontak fazla bir spor. Rakibin atış koluna basmak kurallara aykırı değil ama bunu bilip rakibin koluna yumruk atmak fiziksel ciddi bir eylemdir" (E14, 23, Hentbol).

Farklı spor branşlarında sporcular arasındaki fiziksel şiddetin yanında taraftar tarafından sergilenen fiziksel şiddet eylemleriyle de defaten karşılaşılmaktadır. Taraftarın tuttuğu takımın ya da sporcunun istenilen performansı ve başarıyı ortaya koyamaması gibi durumlarda daha yıkıcı bir boyutta şiddete başvurulduğu gözlenmektedir. Bu şiddet ekonomik, psikolojik ve fiziksel olabildiği gibi bütüncül bir şekilde gözlemlenmektedir. Taraftar şiddetini farklı spor branşlarından K3, K4, E8 ve E9 kodlu sporcuların şu şekilde anlamlandırmaları söz konusudur:

"Futbol maçlarında, taraftarların yenilgi veya galibiyet duygusuyla oluşan psikolojik nedenlere de dayanarak sahaya yönelik ya da kişilere yönelik çok fazla şiddette bulunduklarını görmekteyiz. Taraftarların sahaya yabancı cisimler atmaları, tribündeki oturaklara zarar vermeleri çok karşılaş̧tı̆ımız durumlardır" (K3,22, Yüzme). "Voleybolda fiziksel şiddete genelde yıldız kız klasmanında denk geldim. Müsabaka esnasında fazla heyecan ya da kazanma hırsından dolay ilk karşılıkl sözlü atışmayla başlayıp, daha sonra fiili bir eylemle yani itme, vurma gibi devam ediyor olay. Daha sonra tribünde olan tanıdıkların dâhiliyle devam ediyor. Tribündeki izleyiciler sahaya girdiklerinde iş çı̆̆ırından çıkıyor" (K4, 22, Voleybol). "Yaklaşık 13 yıldır futbol oynuyorum. Fiziksel şiddete en çok antrenmanlarda maruz kallyorum. Çünkü bir forma savaşı var. Bunun dışında bu sene bir maçta rakip takımın sporcuları ve seyircisi tarafindan statta ciddi dayak yedik. Rakiple girilen olumsuz diyalog sonucunda seyircilerin sahaya girip bizim takımı ciddi hırpaladı̆̆ını söyleyebilirim. Polis durumu zor kontrol altına aldı. Benim kaşım patlamıştı" (E8, 25, Futbol). "3-4 yıl önce deplasmanda olduğum bir maçta izleyicilerden birinin sahaya çakmak firlatıp boynuma gelmesi şahit olduğum bir durum” (E9, 21, Voleybol).

Sporda rakip, rakip takım, rakip seyirci gibi grup dışı etmenlerin fiziksel şiddeti nasıl ortaya çıkardığını araştırmaya katılan sporcuların söylemlerinden hareketle analiz etmeye çalıştık. Bu tür fiziksel şiddet unsurları spor alanlarında çok karşılaşılırken, sporda grup içi dediğimiz takım içi fiziksel şiddet olayları da söz konusudur. Bireysel sporlarda ve takım sporlarında çok sık rastlanan antrenör-sporcu arasında yaşanan fiziksel şiddet eyleminden bahsetmek gerekir. Araştırmaya katılan K7, K9, K11, E5 ve E9 kodlu sporcuların şu söylemleri bu fiziksel şiddet türünün anlamlandırılmasında etkilidir: 
"Fiziksel şiddete voleybolda maç esnasında çok nadir karşılaşıllır. Fakat antrenör-sporcu arasında gerilmeler, ikili diyaloglar ilerledikçe fiziksel şiddet oluşmaktadır. Kendimden örnek verirsem, antrenörüm maç esnasinda kritik sayı oynanırken topu dışarı attığım için saha içerisine girip beni silkelemişti. Bir takım arkadaşıma da ona karşı geldiği için bench beklerken tokat atmıştı" (K7, 21, Voleybol). "Salonda ailesi tarafindan sahip çıkılmayan 2-3 sporcu vardı. Antrenörüm bunların özel hayatı kısacası her şeyine karışıp hükmetmeye çalışıyor, birde bir şey yapmasalar bile bir şeyi bahane edip dövüyordu. Onlarda ailelerinin desteği olmadı̆̆ için ve ilerlemek için dayanmak zorunda kallyorlardı" (K9, 26, Boks). "Sporda genel olarak fiziksel şiddet vardir. Bu birazda sporcunun ahlakıyla ilgilidir. Bazı sporcular maç esnasında ya da sonrasında kaybetmenin verdiği sinir ile karşı takıma fiziksel şiddette bulunabilir. Genelde bu şekilde karşımıza çıkar. Ya da tribündekilerin sahaya inip sporculara şiddette bulunmasına çok rastlanır. Benim maçlarımda gözlemlediğim özellikle yenilgi sonrası şiddet psikolojik başlayıp fiziksel olarak sonlanır. Bazen de antrenörün sporcuları fiziksel şiddet uyguladı̆̆ını görürüz”" (K11,23, Basketbol). "Eskrim antrenmanlarında hocamdan teknik ders alırken yaptığım yanlış hareketleri vurarak düzeltmesini örnek olarak verebilirim" (E5, 23, Eskrim). "Kaybettiğimiz bir maçta arkadaşımın soyunma odasının kapısına yumruk atıp kırması ve antrenörümüzün o arkadaşımızı tekme tokat dövmesi söz konusuydu. Arkadaşın hırsina mi yoksa antrenörün arkadaşı dövmesine mi yanayım” (E9, 21, Voleybol).

Sporda fiziksel şiddet olaylarında en fazla göze çarpan durumların başında hakeme karşı yapılan fiziksel şiddet gelir. Taraftar, sporcu, antrenör üçlemesine oranla hakeme karşı fiziksel şiddet daha düşük seviyede gözlenmektedir. Böyle bir şiddet türü söz konusu olduğunda kamuoyunda da çok fazla gündem olması söz konusudur. Bu duruma en güncel örnek olarak, geçtiğimiz günlerde Gana'da kadın futbol takımları arasında düzenlenen bir turnuvada oynanan yarı final maçının son düdüğünün ardından mücadelenin kadın hakemi Theresa Bremensu, bir erkek seyirci tarafından fiziksel saldırıya uğradı. Müsabakanın sonunda yeteri kadar uzatma oynatmadığı için saldırıya maruz kaldığı öğrenilen FIFA hakemiyle ilgili olarak Gana Futbol Federasyonu Normalleştirme Komitesi'nden de açıklama geldi. Saldırıyı sert bir dille kınayan komite, failin gerekli cezayı alacağını vurguladı (Haberler.com, A.T. 01.05.2019). Bu tür olayların dünya spor basınında önemli yer tutması söz konusu iken ülkemizde de diğer fiziksel şiddet türlerine göre az sıklıkla yaşanmaktadır. Hakeme karşı fiziksel şiddet olayını araştırmaya katılan K2 ve E11 kodlu sporcular şu şekilde anlamlandırmaktadır:

"Atletizm hakemliği yaptı̆̆ım sırada bir sporcunun yarışma esnasında koşarken üstüme tükürmesi fiziksel şiddete verebileceğim en somut örnektir" (K2, 22, Boks) "Futbol müsabakası esnasında en çok karşılaştıklarımdan birisidir. Bazı futbolcular agresif oldukları için kendilerine faul yapıldlğı sırada hemen orada art niyet arar bir fiziksel şiddet (itme gibi) uygular. Yine agresif sporcular kendisine faul verilmediği gerekçesiyle hakemin üstüne yürür ve el kol hareketiyle hakemi sarsar. Ĕger ev sahibi avantajı varsa tribün baskislyla bir fiziksel şiddet uygulanır ki bu en kötüsüdür" (E11, 23, Futbol).

\section{Tema 2: Sporda Psikolojik Şiddetin Anlamlandırılması}

Sporda psikolojik şiddetin fiziksel şiddet gibi somut olarak gözlemlen(eme)mesine karşılık, kısa ve uzun vadede motivasyon ve performans düşüklüğüne sebep olmasından ötürü yansımaları oldukça yıkıcıdır. Yaptığımız araştırmada, "aşırı kaygı", "küçük düşürme", "aşağılama", "hakaret", "tehdit", "küfür" gibi kavramlardan hareketle Sporda psikolojik şiddet anlamlandırılmaya çalışılmıştır. Araştırmaya katılan kadın sporcular erkek sporculara oranla bireysel spor branşlarında antrenörlerinden daha fazla psikolojik şiddet gördüklerini belirtmişlerdir. İlk olarak bireysel sporlara baktı̆̆ımızda K1, K2, K9, K12 ve E5 kodlu sporcuların antrenörlerinin aşağılayıcı söylemlerini şu şekilde ifade ettiklerini görmekteyiz:

"Atletizmde yarış esnasında psikolojik baskı çok olur. Antrenörün payı çok yüksektir. Eğer koşu temponuzu beğenmiyorsa kenardan "koş geri zekâlı" ya da "beceriksiz", altı üstü koşuyorsun gibi birçok ifadeyle motivasyonunuzu düşüren ve sizi altüst etmeye yeterli söz duyarsinız" (K1, 25, Basketbol). "Boks milli genç bayanlar takımında müsabakaya çıkıyorum. Hocanın aşağılayıcı ve işe yaramazmışım gibi konuşmaları motivasyonumu yerde bir ediyordu. Kazanabileceğim müsabakayı bile mağlubiyetle bitirdiğim zamanlar oldu”" (K2, 22, Boks). "Sporda psikolojik şiddet her spor dalında çokça karşılaşılan ve kendi gözlemim olan dövüş sporlarında çok daha fazla. Kendimin de maruz kaldığım daha fazla çalışıp çabalayıp bir şey yapmaya çalışırken, fiziki koşullardan dolayı diğer arkadaşlara maçlar için daha çok şans verilmesi, sen yapamazsın diye maçlara gidememek insanı hiçbir şey yapamıyormuş gibi geriye itiyor" (K9, 26, Boks). "Türkiye şampiyonasina gittiğimde öncesinde bir sakatlık yaşamıştım ve maça psikolojik olarak hazır değildim. Daha sonra maçlara başlamadan önce hocam sen yaparsin edersin diye beni motive etti. Çok büyük bir beklenti söz konusuydu fakat ben bu beklentiyi karşılayamadım. Türkiye şampiyonasında 3. Oldum. Maçtan sonra hocam minderden çıktığımda bütün seyircilerin karşısında beni itip kakarak soyunma odasına götürdü ve bir sürü laflar söyledi. 
Senden adam olmaz, boşuna yapıyorsun, korkuyorsan gelme, salak mısın? Söylediğimi anlamıyorsun daha birçok şey sonrasında beni o kadar çok rencide ettiği bu laflar o kadar çok zoruma gitti ki spora karşı içimde o an bütün istek gitti. Sporu bırakmaya bile karar vermiştim" (K12, 24, Judo). "Sporda psikolojik şiddet bir antrenörün sporcusuna yapacaksın, yapmak zorundasin gibi sözlerle sporcusuna psikolojik baskl şiddette günümüzde çoğu branşta görülmektedir. Sadece kötü söz, küfür ya da argo kelimelerden oluşur diyemeyiz. Kişiye yapılan küçük düşürücü el-kol hareketleri de bunun içindedir” (E5, 23, Eskrim).

Yine bireysel sporlarda sporcuların antrenörlerinin arka bölgede ${ }^{3}$ (antrenmanlarda) ya da müsabakalarda tehdit, baskı, sert ve kırıcı söylemleriyle karşılaşmaları, sporcularda kaygı ve motivasyon kaybına sebebiyet vermektedir. Bu durumu K3, K5, K8 ve E1 kodlu örneklemler şu şekilde ifadelendirmektedir:

"Antrenörlerin rekabet duygusu, kazanma hirsl dolaylsıyla sporcuya ağır hakaretlerde bulunması. Antrenmanlar sırasında kapasitenizi aşmanıza rağmen yine de bir şeylerin dayatılması" (K3,22, Yüzme). "Psikolojik şiddeti branşımda yaşadım. Antrenörüm çok baskl yaptı̆̆ı sert ve tepkili konuştuğu için benim moral olarak iyi olmam gerekirken psikolojik olarak düşüş yaşadım. Bu da yarışmaya girdiğimde stres yapıp boğulmama neden oldu” (K5, 24, Yüzme). "Genelde antrenör-sporcu arasinda psikolojik şiddetle karşılaşıyoruz. Bu maçı alamazsan gözüme görünme, sporu bırak, emeklerime yazık gibi birçok psikolojik anlamda etkiliyor ve bu stresle maçları kaybettiğim çok oluyor. Kazanabileceğim çoğu maçı bu şekilde kaybediyorum ve spora olan tüm hevesim kayboluyor" (K8, 27, Muay Thai). "Güreşte sporcu maç esnasında antrenörün köşeden bağırmasına şunu yap bunu yap diye sözlü müdahalede bulunması bazen sporcuyu ateşlemekte ve maçı kazandırmakta iken çoğunlukla olumsuz sonuç doğurmaktadır. Sporcunun maç esnasında antrenörün köşseden bağırdı̆̆ını duyduğunda panik yaparak istediği hareketleri yapamayıp maçı kaybetmesine neden olur" (E1, 26, Güreş).

Takım sporlarında antrenör tarafından sporculara uygulanan psikolojik şiddete aşırı kaygı ve aşağılama durumları diğer bireysel sporcuların söylemlerine paralellik gösterirken takım sporlarında takım arkadaşlarının da sporcuya psikolojik şiddet uygulaması söz konusudur. Bu durumu K7 ve E8 kodlu örneklemler şöyle anlamlandırmaktadır:

"En fazla yaşandığını düşündüğ̈̈m psikolojik şiddettir. İlk olarak branşımda takıma ait bir sorumluluktan dolayı aşırı kaygl, antrenörümün yapamadığım takdirde beni azarlayacak olmasl, takım arkadaşlarımın o zaten yapamazdı deyip yapacaklarımın önüne geçmesi veya tam tersi çok büyük beklentilerin olması, maç esnasında sakatlanmak vb. durumların ylkıcı etkisi var" (K7, 21, Voleybol). "Rakip taraftarın küfrü birde yapılan hata sonucu antrenörün aşağılaması ya da takım arkadaşlarının bir sözü olumsuz etkiliyor. En çok futbolda psikolojik şiddet var bence" (E8, 25, Futbol).

Sporda psikolojik şiddet olgusunun bir diğer ayağı olan ve en çok gözlenen seyirci şiddetidir. Bireysel sporlara nazaran takım sporlarında seyirci tarafından sporcuların ve hakemin psikolojik şiddete maruz kalması söz konusudur. Seyirci tarafından sergilenen psikolojik şiddet oyuncuların motivasyonlarının kaybetmelerinde ve performanslarının düşmesinde etkilidir. Ayrıca sporculara göre müsabaka/maç esnasında psikolojik şiddete maruz kalan hakeminde istemsiz olarak yanlış karar verdiği durumlar çok olmaktadır. Takım sporları göz önünde bulundurulduğunda K1, K4 ve K11 kodlu kadın sporcular bu tür şiddeti şu şekilde anlamlandırmaktadır:

"Basketbolda ise en büyük etken tribünlerdir. 2 hafta önce bulunduğum basketbol maçı taraftarlarının yuhalamalarl, küfürleri vs. yüzünden hakemin adaletsizce maçın seyrini değiştirdiğini gördük” (K1, 25, Basketbol). "Voleybolda psikolojik şiddet hem oyuncu hem de hakem üzerine oluyor. Tribünden çoğunlukla oluyor. Hakemlere de genellikle kritik bir sayıda rakibe verilen sayılarda karar doğruda olsa takım kaptanı ya da antrenörler tarafindan psikolojik şiddet uygulaniyor" (K4, 22, Voleybol). "Psikolojik şiddeti spor alanlarının hepsinde görmek mümkün. Bu durum sporcunun maç esnasındaki performansina yansir, hem de daha ileri gittiğinde fiziksel şiddete dönüşerek ceza almasına yol açabilir. En çok seyircili branşlarda psikolojik şiddet görülür” (K11,23, Basketbol).

\footnotetext{
${ }^{3}$ Arka Bölge; Erving Goffman'ın Dramaturjik teorisinin temel kavramlarındandır. Kılıç 2015 yılında yazdığı Dramaturjik Teori Ekseninde Spor adlı makalesinde teoriyi spor kurumuna uyarlamıştır. Bu uyarlamada arka bölge, sporculardan seyircilerin beklendik davranışları dışında, rahat hareket edebilecekleri ve ekip üyelerinin etkileşiminin rutine uygun performans ortaya koymaya gerek duymadıkları alanlardır. Bu açıdan Kılıç'a (2015b) göre antrenmanlar, sporcu, takım üyeleri ve antrenör arasında arka bölge olarak ortaya çıkmaktadır. Bu tür alanlarda seyircinin izlenim idaresine ihtiyaç yoktur. Ekip (takım) üyelerinin birincil samimi ve rahat ilişkiler geliştirdiği alanlardır. Arka bölgede sporcuların ve antrenörlerin doğal davranışlarını sınırlayacak bir etken yoktur.
} 
Takım sporları içerisinde yer alan farklı spor branşlarında erkek sporcularında kadın sporcularla benzer düşünceleri paylaştıkları söylenebilir. Seyirci, hakem ve antrenör tarafından sergilenen psikolojik şiddetin zincirleme olarak devam ettiğini E9, E10, E11, E12, E13 ve E14 kodlu sporcular şu şekilde anlamlandırmaktadır:

"Bizim tribünler çok yakın olduğundan ve kapalı salon olduğundan ciddi anlamda söylenenler duyuluyor. Tribünden çok defa hakaret yedik. Antrenörün kenardan çok defa rencide etmesi aşağılaması söz konusu, senden olmaz sen beceremezsin demesi ya da ailene bu çocuğu alın bundan sporcu olmaz demesi gibi yaşanmış örnekler verebilirim" (E9, 21, Voleybol). "Genel olarak ülkemizde sikça görülen bu şiddet türü seyircilerin, antrenörlerin, rakip oyuncuların sözsel, mimik $v b$. yollarla gösterilebiliyor. Yıllardır sporun içerisindeyim branşımın basket olmasına rağmen ülkemizde en çok popülaritesi olan futbola ilgimde fazla. Evim stada çok yakın olduğu için yıllardır amatör futbol maçlarını izliyorum. Amatör futbol futbolcuların amatör olduğu kadar diğer yapılanmalarında amatör olduğu bir durum söz konusu. Seyirciler, hakemler vb. yillardir seyircilerin bilinçsizce oyunculara, antrenörlere, hakemlere, diğer rakip taraftarlara sözsel olarak şiddet uygulaması, futbolculara "senin ayakların keserim bir daha top oynayamazsın" gibi laflar sporcuyu olduğu kadar hakemi de etkilen bir süreçtir" (E10, 22, Basketbol). "Kendi sahanızdaysanız ilk başlarda taraftarlar marşları ve besteleri söylerken takımları mağlup durumdaysa oyunculara, golü atamayana, yanlış pasverene küfürler saydırırlar. Takım 2 kez kaybettiğinde antrenörü istifaya çağııırlar, daha çok kaybederse kulüp başkanlarının istifasın isterler. Bu durumlarda da başkandan ya da antrenörden daha çok bask yiyen yine sporcular olur. Gerisini siz düşünün" (E11, 23, Futbol). "Maç esnasında oyuncunun hata yapmasına saha dışında antrenörün oyuncuya bağırmast, seyircinin diğer takımın sporcularına toplu ya da bireye küfürlü tezahürat etmeleri" (E12, 25, Futbol). "Hentbolda psikolojik şiddet müsabakanın gidişatın olumlu-olumsuz etkileyebilir. Salon sporlarında çok yaşanır. Antrenörün bağırması kulaklarınızda çınlar, seyircinin de" (E13, 24, Hentbol). "Hentbol branşında yakın temas olduğu için ve de saha ölçüleri küçük olduğu için sporcular birbirlerine yakın mücadele eder. Buda sözlü olarak konuşmalarında kolaylık sağlar. Sporular rakiplerini moralman oyundan düşürmek için küfür, kötü sözler kullanırlar.... Gole giderken rakip tribünün sahayı uğultulara boğması olabilir. Rakibe kollarını açarak sevinmen, sert bakman ya da takım sporlarında mali yönden iyi bir takımın mali yönden çok kötü takımla karşılaşması da psikolojik şiddettir” (E14, 23, Hentbol).

Sporda bir diğer psikolojik şiddet türü de sporcular arasında yaşanan şiddettir. Rakibin sporcunun motivasyonunu dağıtmak en kolay başvurabildiği şiddet şeklidir. Bu durumu K6 ve E11 kodlu sporcular şöyle izah etmektedir:

"Voleybolda psikolojik şiddetin çok olduğunu düşünüyorum. Rakiple karşı karşıya geldiğinizde gözlerinizin içine bakarak yüksek sesle bă̆ırmaları, jest mimiklerdeki değişik hareketler motivasyonunuzu olumsuz etkiliyor" (K6, 21, Voleybol) "Çok önemli maçlarda olur genellikle. Hatanın telafi olmadiğı maçlarda rakibi eksik bırakmak amacıyla birebir oynadĭ̆g futbolcularla hakeminde uzak durması nedeniyle küfür etmeye başliyor" (E11, 23, Futbol).

Son olarak sporda psikolojik şiddet unsuru olarak sporcuların rakibi hakkındaki ön yargıları oluşturmaktadır. Ben/Biz ve Öteki ayırımının yapılması ve ötekine yüklenen anlamlar sporcuda psikolojik bir baskı yaratmaktadır. Bu baskıda motivasyon eksiliğine sebebiyet vermektedir. $\mathrm{Bu}$ durumu E3 ve E4 kodlu örneklemlerin ifadelerinde somutlaştırmak mümkündür.

"Anadolu kulübünde spora başladiğım için insanlar bizlere farklı gözle baklyorlardı ve diğer büyük kulüplerin sporcuları bizlerle arkadaş olmuyorlard ve bu sizi olumsuz etkiliyordu” (E3, 22, Yelken). "13 senedir tekvando sporu yaplyorum ve birçok Türkiye şampiyonluğum var. Maçlara gittiğimizde tartılar ve kuralar maçtan bir gün önce çekilir. Bu sayede kilonda kimin olup kiminle karşılaşabileceğini görebiliyorsun. Maça çımadan, dövüşmeden bu sana psikolojik şiddet olarak yansıyabiliyor ve ön yargı ile maça çıkı maçı kaybedebiliyorsunuz" (E4, 24, Tekvando).

\section{Tema 3: Sporda Ekonomik Şiddetin Anlamlandırılması}

Sporu elit spor seviyesinde yapan sporcuların ekonomik anlamda ihtiyaçlarını spor kurumundan karşılamaları söz konusudur. Sporda ekonomik sınırlı1ık/yoksunluk yaşanması ekonomik şiddet olarak ortaya çıkarken, bu şiddet türü arka planda sporculara psikolojik şiddet olarak dönmektedir. Ekonomik şiddet nadiren de olsa bazı durumlarda fiziksel şiddeti doğurmaktadır. Sporda ekonomik şiddete maruz kalan sporcuların iyi bir performans sergilemesi zorlaşmaktadır. Araştırmaya katılan sporcuların; "boyun eğme", "hakkımıza göz dikme", "vaatlerde bulunma", "adam kayırma", "kısma", "ekipman yoksunluğu" olarak ortaya koydukları kavramlardan hareketle tema 3 oluşturulmuştur.

Araştırmaya katılan farklı bireysel sporlarla uğraşan sporcuların birçoğu emeğinin ekonomik karşılığını yeterince alamadı̆̆ını belirtmektedir. Cinsiyet farkı gözetmeksizin bireysel sporlarla uğraşan 
sporcuların söylemlerinde, genel olarak sporcular arasında eşit ücret dağılımı olmadığı, ekipman yönünden rakiplerle aynı nitelikte olmadıklarını, antrenörlerin çoğunlukla sporcuları sömürdüklerini, sporculara verilen prim ya da sponsorluk gelirlerinin tasarruf hakkının antrenörlerde olduğunu ve bu paralara genellikle antrenörler tarafından el konulduğunu söylemek mümkündür.

"Yüzme sporu üzerinden iki farkll rakip sporcunun kulüplerinde birinin ekipman yönünden her türlü olanağa sahip olması, diğerinin ise bazı ekonomik nedenlerden dolayı yeterli düzeyde yarışmaya hazırlanamaması ve başarısız olması en büyük ekonomik şiddettir (K3,22, Yüzme). "Ben 50 metre serbesti 28 saniyede yüzüyor ve kulübüme iyi olduğum için para ödemiyordum. Bu zamanda da yaşım ilerlediği için artık kulüp para almaya ve yaş gurubum kalmadığ için antrenmanlarda üstümdeki ilgiyi çekmişlerdi" (K5, 24, Yüzme). "Kulübün ekonomik imkânları çok yetersiz. Geçenlerde maçlara gidecektik ama 2 bin tl masraf çıktığ için gidemedik. Spor salonunda çalışlyorum ve çok fazla saat çalışıyorum emeğimin karşılığını aldığımı düşünmüyorum” (K8, 27, Muay Thai). "Özel kulüpte sporcu olunca dlşarıdan destek alamıyorsun ve bazı maçlara gidememek ekonomik bir şiddettir. Yine bazı maçlarda hoca fazla para alıp istediği yani sevdiği sporcuları para almadan maçlara götürürken biz paramızla götürmesi ekonomik bir şiddettir. Gireceğimiz şehirde hem fazla para alip, hem de hiç para vermemişiz gibi muameleye maruz kalmak, dereceğe girince devletin verdiği harcırahı kendine kullanmasl, yani hakkımıza göz dikmesi ekonomik şiddettir. Türkiye'de birçok antrenör bunu yapıyor maalesef, sporcuyu ve ailesini zor duruma sokuyor" (K9, 26, Boks). "Sporda oldukça başarllyydım. Büyük kulübe transfer oldum 15 yaşlarındaydım. Artık zevk için değil de kendim için gelebileceğim son noktaya gelmek için. Kendi şehrimde en üst düzey olan kulübe başarılarım sayesinde transfer olarak az miktarda bir paraya lisansımı çıarttım. Başka bir kişi benim 2-3 katı yüksek miktarda maaş alıyorlar. Ben bu durumu sorguladığımda cevap alamıyorum. Toplantı zamanı benim gibi bu durumdan rahatsız olanlar konuyu açıyor ve bizim değişimizle adam kayırma nasıl oluyor onu gösteriyor hocalarımız. Verilen cevap arkadaşınız okullar arası Türkiye şampiyonu o yüzden maaşı yüksek. Okullar arası kulüp ile bağımsız gelir bile kazandırmıyor. Kendi 5 katı başarılarımı ortaya koyuyorum ama bir şey değişmiyor" (E1, 26, Güreş) "Kendimden örnek verecek olursam sporda çok kisa zamanda milli sporcu olmayı başardım ama çok sakatlık yaşadım. Maç esnasında antrenmanlarda bu sakatlanmalarımın tedavi sürecinde olan maddi giderin bir kısmını kulübüm, geri kalan yüklü miktarı ailem ödedi. Ekonomik yönden çok zarara uğradı ailem. Sonuç olarak ben o kulübün sporcusuyum. Çok kısa sürede kulübüm için birçok madalya kazandım. Kazandığımın karşılığını bana ekonomik anlamda vermeseler de en azından hakkım olan sağglk konusunda her şeyin yapılması gerekirdi" (K12, 24, Judo). "Ayrıca korsan yani karaborsada satılan maç biletlerini örnek verebiliriz ve yine sporcuların düşük performanslarını aldıklarını ücrete örnek olarak verebiliriz" (E2, 35, Karate). "Bireysel sporlarda bazı sporcuların maddi durumları iyi olduğu için malzemelerin bir kısmının karşılanmaması ya da başarıll sporculara malzeme vermeleri başarısız olanlara malzeme verilmemesi, antrenörlerin müsabakalarda yemek parasindan kısı otele veya cebine koyması ekonomik şiddettir" (E5, 23, Eskrim) "il seçmesinde derece yapıldı̆̆ında belediye maddi destek veriyordu Türkiye şampiyonası için. Benim ve arkadaşlarımın aldiğı paranın yarısını da hoca kendine alıyordu. Bu duruma karşı çıkıldığında karşı çıkanlar için belediyeye maddi destekte bulunmayacağını söyleyerek tehdit ediyordu. Bizde mecburen kabul ediyorduk" (E6, 22, Wushu Sondu-Çin Boksu).

Takım sporlarına bakıldığında cinsiyet farkı gözetmeksizin sporcuların, bireysel sporlarla uğraşan sporculara paralel ifadeler kullandıkları görülmektedir. Farklı spor branşlarındaki sporcuların ekonomik şiddet algılarını şu ifadelerde görmek mümkündür:

"Kazanılan her müsabaka ve şampiyonluk adına antrenörümüze yapılan ek ödenek hiç tarafimıza ulaşmadı ve birde ihtiyacımızın karşılanması için toplanan parayı kullanamayıp bizden para toplayıp gerekli şeyleri alırdık. Suyu bile" (K1, 25, Basketbol). "Voleybol alt liglerinde yani bölgesel, mahalli liglerde sporculara ekonomik olarak destek verilmiyor. Vaatlerde bulunup üst liglere çıkmak için sporculara ekonomik olarak destekte bulunulacağı söylenip bütün çabalarını, istediklerini, arzularını ortaya koydurduktan sonra hak edilen şeyler kulüp tarafindan karşılanmadığı için tanıdığım çoğu sporcu ya sporu bıraktılar ya da başka kulüp arayışına geçiyor. En çok karşılaş̧ı̆̆ım şiddet oynadığım kulüplerde ekonomiktir" (K4, 22, Voleybol). "Voleybolda rastladı̆̆ım oyunculara hakkettikleri paranın verilmemesi. Bulunduğu konum ile verilen ücretin ayn olmaması ve en önemlisi sporcuların farkl ü̈retlere tabi tutulması" (K7, 21, Voleybol). "Kulüple anlaşan bir sporcu parasını alamadı̆̆ taktirde spordaki performansında düşüşler olur. Kulüple arasında sorunlar çıkabiliyor" (K11,23, Basketbol). "Birinci ligde oynamama rağmen çok düşük ücret almam ve ihtiyaçlarım yeterince karşılanmadan oynuyordum. Bu da bende negatif etki yaratıyordu. Aynı takım arkadaşlarımdan bazılarının çok iyi ücretler alıyor olması antrenmanlara ya da maçlara içtenlikle gitmemede etkendi. Bunlar benim o takımı bırakmamda etkendi" (K13, 22, Voleybol). "Geçen yaz anlaşmış olduğumuz hentbol takımında 2 farkl guruba gidecektik. Iyi bir takımdık zaten lige çıkacaktık anlaşmamız masraflar karşılanması olarak sonuçlandı. Asıl parayı lige çıkınca kazanacaktık. Maçlarda kırmıza kart görerek 2 maç oynamadım ama maç başı anlaşmadı̆̆ımız için bir ücret kesilmemesi gerekiyordu. Fakat benden 2 maç için $x$ tl para kesilmiş, oynadiğım 7 maç için x para verilmişti. Kesilen par verilen paranın $3^{\wedge}$ te 2 'si ne denk geliyor" (K14, 24, Hentbol). "Amatör kulüpte oynuyorum. Belli bir maç başına anlaşıyorsun ama ayda alacağın paranın yarısını alamıyorum. Bu da 
sürekli bir şeylerden kısma şeyi doğuruyor bende hak ettiğim parayı alamayınca direkt hayatımı etkiliyor" (E8, 25, Futbol). "Kendi kulübümde oynayan bir Amerikalı oyuncunun dolar kuruyla çok yüksek ücret almasina karşın benim Türk lirası kurundan ücret almam ve aramızda yetenek farkı olmamasına rağmen aradaki ücret farkının bu denli yüksek olması ekonomik şiddettir. Yapılan sözleşmelerde maddi olarak ödenmesi gereken günler bile geçiyor ama buna mahkum kalyyoruz. Ayrica psikolojik şiddete dönüşüyor bu durum” (E10, 22, Basketbol). "Ben futbolu amatör olarak oynadı̆̆ımdan en çok karşılaştı̆̆ım sorundur. Mesela transfer olduğum kulübün hedefi şampiyonluk ve ben aylık maaşla oynayan biriyim. Ĕger ki şampiyonluk şansı kalmazsa kalan maaşlara da el konuluyor. Bu ciddi sıkıntılar oluşturuyor. Bir imza söz konusu olmadiğından kendini savunmayıp bu şekildeki durumlara boyun ĕgmiş oluyorsun. Şampiyon olun şu kadar prim deniliyor, şampiyon oluyorsun söz yine tutulmuyor ve ciddi anlamda emekler boşa gidiyor. Sezon sonu son maaşı almaya gittiğimde zarfin içinde para eksik oluyor. Bunu sorduğumda bir yanlışlı olmadiğını fazla fazla verdiklerini söylüyorlar. Biz o kulübü sevdiğimizden değil para kazandığımızdan o kulübe emek veriyoruz. A kulübü veya b kulübü önemli değil" (E11, 23, Futbol). "Yaklaşık 7 ylldır para kazanarak meslek olarak futbol oynuyorum. Ancak şuan 3 aydır paramı alamıyorum Sporcuların kulüpten paralarını alamamaları sporculara hem psikolojik hem de ekonomik şiddet etkisi yaratır ve o yüzden sporcudan yüksek performans beklenemez" (E12, 25, Futbol). "Sporcunun alacaklarının ertelenmesi ya da alamamass durumu ekonomik şiddettir. Hentbol 2. Lig sporcusuyum ve genel olarak takım geliri yetersiz olduğu için maç başına anlaşılmış ücretlerin tarihi değişiyordu. Bu durum psikolojimi de etkiliyordu, maçlarda etkili olamıyordum” (E13, 24, Hentbol).

\section{Tema 4: Sporda Cinsel Şiddetin Anlamlandırılması}

Sporda cinsel şiddet üzerine çok fazla düşünülmeyen, bilimsel olarak çok fazla çalış1lmayan bir alan olarak görülmektedir. Elit spor bağlamında sporcuların diğer şiddet türlerine oranla daha az karşılaştıkları bir şiddet türü olmasına rağmen gerek mesleki, gerekse bireysel ve toplumsal manada yıkıcı etkilerinin en çok gözlendiği şiddet türüdür.

Sporcuya yapılan cinsel şiddetin anlamlandırılması için sporcuların "göz boyama", "duygu tatmini”, "iğrenç bakış", "fiziğine göz gezdirme", "farklı dokunuş" gibi ortaya koydukları kavramlardan hareket edilmiştir. İlk olarak bireysel sporlarla uğraşan kadın sporcuların antrenör-sporcu arasındaki cinsel şiddet izahlarına yer verilecektir. Bu manada K8, K9 ve K10 kodlu örneklemlerin şu ifadeleri antrenör tarafindan sporcuya uygulanan cinsel şiddetin anlamlandırılmasında önemlidir:

"Bizim sporda cinsel şiddete şahit oldum. Eski antrenörüm maddi anlamda gözümü boyamaya çalışmıştı. Ben henüz 14 yaşlarımda iken cinsel istismarda olmuştu. Ama ben bunu kimse ile paylaşamadım ve o antrenörümü bıraktım. Sonrasında eski antrenörüme öğrencisiyle taciz olayı olduğu için dava açılmıştı. Yalnız kızın abisi hocay bıçakladı ve hapse girdi. Hoca iyileşti ve kız sonradan şikayetçi olmadı̆̆ı için hocada serbest bırakıldı" (K8, 27, Muay Thai). "Böyle bir şeye hiç şahit olmadım ama duydum. Bizim kulüpte 2 klz vardl. Benim başladığım sene bırakmışlar kızlar başarılı ve hoca içlerinden birisine aşık olmuş, kız böyle bir şeye karşılık vermemiş, ısrarla taciz etmiş, feyk hesaplardan rahatsız etmiş ve kız kulübü bırakmış" (K9, 26, Boks). "Antrenörün sporcusuna cinsel istismarda bulunması cinsel şiddettir. Jimnastik branşında daha fazladır. Sporcular küçük yaşta başladı̆̆ı için fazladır. Antrenörün sporcuyla evlenmesi de cinsel istismarin uzantisidir" (K10, 22, Atletizm).

K10 kodlu sporcunun söyleminden hareketle, bireysel sporlar birebir çalışmayı öncelediği için antrenör ile sporcu arasında özellikle antrenmanlarda temas söz konusu olabilmektedir. Bu temasın spor kültürü ve ahlakına uygun olmadığı durumlarda cinsel şiddet ortaya çıkması muhtemeldir. Bu açıdan bireysel spor dallarında Antrenörün kadın sporcuya cinsel şiddeti takım sporlarına nazaran daha fazladır.

Antrenörün yanında seyircilerinde cinsel şiddetinden söz etmek gerekir. Cinsel şiddet olgusu fiziksel temasın ötesinde, kişinin bir cinsel obje olarak görülmesi, gözle ya da sözle taciz edilmesini de (Kilıç, 2017) kapsamaktadır. Araştırmaya katılan kadın sporculardan K1, K2, K3, K5, K6, K13 ve K14 kodlu sporcuların seyircilerin bakışlarından ve sözlerinden hareketle yaşadıkları cinsel şiddeti aşağıdaki gibi ifadelendirmeleri söz konusudur:

"Atletizm, basketbola oranla biraz daha problemli şu konuda elinden geldiğince koşacaksın saçın, küpen, şortun her şeyin rahat olmalı dikkatini dağıtmamak için. Bu yüzden kısa şort ve yarım atlet hep tercihimizdir. Ben koşarken şortun kısalı̆ğndan bacaklarımıza kadar iğrenç bakışa ve söze maruz kaldı̆̆ımızı bilirim. Taraftar çok önemli o yüzden. Bundan 10 sene önce nabız ölçme, kalp atımı ölçme için bu kadar teknolojik imkân yoktu. Bizim antrenörümüz bizi hep elle kontrol ederdi. Gel bakayım kalbin hizlı atıyor mu?, şuraların ăgrtyor mu?...iğrençti bunlar" (K1, 25, Basketbol) "Cinsel şiddeti daha çok bayan voleybol müsabakalarında gözlemliyorum. Gerek seyirciden gerekse antrenörden vs. çok karşılaştığım bir durum. Kısa şort giyen sporcuların cinsel bölgelerine baklşların yoğunlaştırılması. Birçok kiş̧inin bu tür müsabakaları sportif doyum için değil başka duyguları tatmin etmek için geldiğini düşünüyorum" (K2, 22, Boks). "Sporda cinsel şiddet vakaları çok olmakta. Bende karşılaştım. Basketbol maçında kadın hakemin kararları yüzünden izleyicilerden 
cinsel içerikli ă̆ır hakaretlere maruz kaldı̆̆ını gördüm" (K3,22, Yüzme). "Yarış zamanlarında tribünden bazı izleyicilerin yoğun bakışlarına maruz kalıyoruz. Rahatsızlığınızı tepkiyle gösteremiyorsunuz ve susmaktan, umursamamaya çallşmaktan başka bir şey yapamıyorsunuz" (K5, 24, Yüzme). "Voleybolda kısa tayt giyiyorsunuz ve tribünden bazen birinin laf atması sizi çok rahatsız ediyor. İçiniz kalkıyor" (K6, 21, Voleybol). "Özellikle voleybolda klsa tayt giyildiğinden ötürü tribünden bazı ahlakslz konuşmalar, laflar olur. Bu da olumsuz etkilenmenize sebep oluyor. Arkadaşlarımın ve benim bu tür iğrenç durumlara maruz kalmışlı̆̆ımız oldu" (K13, 22, Voleybol). "Toplumumuzun en büyük sorunlarındandır. Amatör sporlar diye tabir edilen seyri az sporların genellikle maç izleyicisi toplandiğg zamanlarda sporcular genelde bayandır. Bu tür maçlar oldukça sıkıntılıdır sporcu için. Bireysel sporlarda antrenörler ile sporcu arasında bu tür şiddet olaylarının yaşandığını duyuyoruz" (K14, 24, Hentbol).

Kadın sporcuların, antrenör ve seyirciden ötürü maruz kaldıkları cinsel şiddeti K11 kodlu örneklem bütüncül açıdan değerlendirmektedir. Spor branşlarının birçoğunun formaların kısa olması, seyircinin seyir kültürünün olmaması ya da başka amaçlarla seyre gelmesi, antrenörün olumsuz tutumu gibi faktörlerin toplumsal yaşamda ailelerin kız çocuklarını spora yönlendirmemesinde etkili olduğunu şu sözleriyle dile getirmektedir:

"Toplumumuzda bayan sporculara karşı genelde bir ön yargı oluşmaktadır. Örneğin bazı aileler çocuklarının voleybol sporu yapmasını istemez. Çünkü maçta giydikleri şortların kısa olduğunu düşünürler. Bu tarz birçok örnek olabilir. Mantık bu tarz olduğu zaman cinsel şiddet ortaya çıkar. Örneğin bir maç izleyen topluluk maçta bayan varsa öncelikle fiziğine göz gezdirip kendi aralarında yorum yaparlar ve bu o sporcuya aslinda cinsel şiddettir. Bu tarz yorumları sporcu duyduğu taktirde onun spor hayatını kötü etkiler. Günümüzde bazı antrenörler bile kendi sporcusunu cinsel şiddet uygulamaktadır. Genellikle bayan sporcularda görülen cinsel şiddete daha çok voleybol, tenis gibi forması kısa olan, vücudunu belli eden sporlarda daha çok ortaya çıkar" (K11,23, Basketbol).

Erkek sporcularında kadın sporcuların bakış açılarına benzer yaklaşımlarda bulunduklarını söyleyebiliriz. E2, E6, E12 ve E14 kodlu sporcuların antrenörlerin temaslarından ve sporcuların formalarından ötürü seyirci tarafından cinsel şiddeti maruz kaldıklarını şu şekilde anlamlandırmaları söz konusudur:

"En çok fitness salonlarında hocaların bayan üyelere bazı hareketleri gösterirken elleriyle ve vücudunun bazı yerleriyle temas ettiklerine şahit olmuştum. Mesela barfiks aletinde yapamadığ için belinden ve kalçasına yakın kısımlardan bayan kavrayı ona sözde yardımcı olması veya leg press aletinde bacaklarına dokunup daha sertleşmemişsin demesi gibi bir çok gözlemim oldu" (E2, 35, Karate). "Bizim branşın yarışmalarına kısa şort ve sıfır kollu tişört ile çıkıllyordu. Ve yarışmaya çıkan bayanlar öküz gibi bakan seyircilerin bakışlarından çok rahatsız oluyorlardl. Genelde seyirci az ve erkek olduğu için kızlar çok tedirgin oluyordu" (E6, 22, Wushu Sondu-Çin Boksu). "Sporda cinsel şiddet daha çok bireysel sporlarda görülür. Erkek antrenörün bayan sporcunun müstehcen yerlerine uzun uzun bakmast veya hareket gösterirken farkl şekillerde temas etmesi durumu" (E12, 25, Futbol). "Sporda cinsel şiddet bayan sporlarinda daha çok olur. Örneğin voleybol, hentbol kısa şort ve tayt ile oynanan sporlardır. Antrenör açık idman yaptı̆̆ zaman sporla ilişkisi olmayan insanların idmanı seyredebilmesi söz konusudur" (E14, 23, Hentbol).

Sporda cinsel şiddet unsuru olarak ortaya çıkan bir diğer unsur ise kadın ve erkek sporcuların birlikte antrenman yaptırılması ve aynı soyunma odalarının kullanılmasıdır. Bu durum E1, E7 ve E3 kodlu erkek sporcuların, "Bizim spor branşında güreşte bayanların ve erkeklerin birlikte beraber antrenman yaptıklarını gördüm ve güreş branşı diğer branşlar gibi olmadı̆̆ için temas gerektiren bir branş olduğu için bayan ve erkeklerin birbirine temas etmesi ve yanlış hareketler doğurduğunu gördüm” (E1, 26, Güreş). "Bizim güreş sporu temas gerektiren bir spor. Antrenmanlarda bayan sporcuları erkek hocaların çalıştırıyor olması başlı başına sıkıntı. Ne kadar iş ahlakı olsa da olmuyor. Çaresiz bayan arkadaşlarımızın sessiz kaldiğı durumlara şahit olduk. Sonrasında aramızda konuştuğumuzda kızların bazı durumlardan iğrendiği ve sporu bile bırakanların olduğunu söyleyebilirim. Ayrıca çevremizden bize bile cinsel şiddet vardır. Yağlı güreşte elinizi nereye sokuyorsunuz gibi sözlerle çok karşılaştım" (E7, 25, Güreş). "Yelken sporu pahalı olduğu kadar bir o kadarda cinsellik açısından geniş spor dalı. Çocukların kız erkek demeden aynı anda aynı yerde giyinmeleri çok fazla mümkün oluyor” (E3, 22, Yelken) ifadelerinde açıkça gözlenmektedir.

\section{TARTIŞMA ve SONUÇ}

Farklı boyutlarıyla sporda şiddetin görünürlüğü günümüz toplumlarında yadsınmaz bir realitedir. Elit spor bağlamında hemen hemen bireysel ve takım sporlarının hepsinde şiddetin yaşanması söz konusu iken, toplumsal yapı içerisinde bireylerin belki de en çok şiddeti kanıksadığı kurumsal alanlardan biriside spordur. Sporun doğası gereği sosyal bütünleşmeye kaynaklık etmesi gerekirken çeşitli boyutlarda şiddetin meşrulaştırılması söz konusudur. 
Yaptığımız araştırmada sporda fiziksel şiddet olgusunun bütün branşlarda yoğun olarak yaşandığını görmek mümkündür. Fiziksel şiddet olgusu takım sporlarında ve bireysel sporlarda sporcu, antrenör, seyirci ve bunlara oranla daha düşük seviyede hakeme karşı yapılarak ortaya çıkmaktadır. Bireysel ve takım sporlarında sporcular arasında fiziksel şiddet olgusunu K10 kodlu örneklemin "Atletizmde yarış esnasında rakibimin bana vurarak düşürmesi çok karşılaştığım durum. Performansımı başarımı olumsuz etkilemek adına birçok defa bu tür temaslara maruz kaldım" söyleminde ve diğer sporcuların benzer söylemlerinde somut olarak görmek mümkündür. Taraftar tarafından uygulanan fiziksel şiddet olgusu göz önünde bulundurulduğunda bireysel sporlarda değil ama takım sporlarında bu tür şiddet olaylarıyla çok fazla karşılaşılmaktadır. Sporcular arasındaki münakaşadan, rakip takımın yaptığı faulden, hakemin kararından, tuttuğu takımın geride olmasından/mağlubiyetinden ötürü sporculara yönelik yıkıcı şiddet eylemleri içerisine girdikleri gözlenmektedir. Yine takım sporlarında antrenmanlarda takım arkadaşlarının forma şansı elde edebilmek için birbirleriyle girdikleri mücadelelerde fiziksel şiddet uygulamaları ve antrenörün sporcuya fiziksel şiddet uygulaması söz konusudur. Araştırmaya katılan E1 kodlu örneklemin "Güreşte sporcunun antrenörün istediği başarıyı elde edememesinden dolayl, antrenörün sporcuya vurduğunu şiddet uyguladiğını gördüm. Bu gibi durumlar sporculart spordan uzaklaştırmaya neden olan durumlardır. Ayrıca antrenmanda çalışlyorsun yorulup mola verdiğinde neden çalışmıyorsun deyip şiddete yine maruz kaldım” söylemi bu durumu özetlemektedir.

Bir diğer şiddet türü olarak sporda psikolojik şiddet, spor alanlarında fiziksel şiddet gibi en çok gözlenebilen şiddet türlerindendir. Kısa ve uzun sürede sporcular üzerinde performans ve motivasyon düşüklügüne sebep olmasından ötürü yıkıcı etkileri vardır. Toplumsal cinsiyet farkı gözetmeksizin bireysel ve takım sporlarında sporcuların antrenör, seyirci ve sporcular tarafindan yoğun olarak psikolojik şiddete maruz kaldıkları araştırmada ortaya konulmuştur. Kadın sporcuların erkek sporculara oranla antrenörleri tarafindan bireysel sporlarda daha fazla psikolojik şiddete maruz kaldıkları tespit edilmiştir. Sporcuların antrenörleri tarafından küçük düşürülme, aşağılanma, hakaret, tehdit, küfür gibi söylemler ve yapılan jest-mimikler gerek antrenmanlarda gerekse müsabakalarda çok fazla karşılaşılan durumdur. Psikolojik şiddet söz konusu olduğunda küfür ve hakaret gibi söylemler ilk akla gelirken gözden kaçırılmaması gereken ve psikolojik etkisi yüksek olan şiddet türleri tehdit ve baskıdır. E7 kodlu örneklemin "Müsabaka öncesinde antrenör bana bu maçı almazsan görüşürüz, bu maçı alamazsan maaşın kesilir gibi ithamlarda bulunması üzerimde aşırı baskl ve gerginlik oluşturuyor" söylemi bu durumu net bir şekilde ifade etmektedir.

Takım sporlarında antrenörün sporculara psikolojik şiddet uygulaması çok fazla karşılaşılan ve bazen de seyirci tarafindan beklenen, istenen bir durum olarak ortaya çıkmaktadır. Örneğin antrenörün müsabaka esnasında sporcunun performansındaki düşüklükten ötürü yıkıcı söylemleri, el kol hareketleri, taraftarın antrenöre saygınlığını arttıran bir davranış olarak gözlenmektedir. Bu durum öte yandan sporda psikolojik şiddetin temellerinin dışsal ve sosyal baskıyla şekillenebilen bir yanı olabileceğini de bize göstermektedir. Yine takım sporlarında gözden kaçırılmaması gereken ve araştırma verilerinden elde edilen, sporcular arasında yaşanılan psikolojik şiddet unsurudur. Burada psikolojik şiddet iki şekilde ortaya çıkmaktadır. İlki aynı takımdaki sporcuların yaşadığı psikolojik şiddet olgusudur. Burada takım arkadaşının performans düşüklüğü müsabakada takımın başarısızlığına sebebiyet veriyorsa sporcular tarafından çeşitli boyutlarda psikolojik şiddete maruz kalınabilir. Ayrıca kişinin yedek kalması/kalmaması ve forma şansı bulması için antrenmanlarda yoğun çaba sarf etmesi de soyut düzlemde bakıldığında takım içi psikolojik şiddet unsurudur. İlkine oranla temas gerektiren takım sporlarında, sporcular arasında daha fazla gözlenen psikolojik şiddet rakip sporcular arasında yaşanmaktadır. Sporcunun rakibin performansını düşürmek için söylem ve hareketleri, rakibin bilinçli ya da bilinçsiz kural dışı yaptığı davranışa karşılık sporcunun söylem ve eylemleri yaptığımız araştırma da ortaya konulmuştur.

Çoğunlukla takım sporlarında psikolojik şiddetin bir diğer ayağı olarak belirttiğimiz ve en çok gözlenen türü seyirci şiddetidir. Psikolojik şiddet, seyircinin rakip sporcuya, kendi sporcusuna ve yine yoğunlukla rakip seyirciye yönelik uyguladığı şiddet türlerindendir. Kitle psikolojisiyle hareket eden seyircinin, çoklu veya birbiri üstüne geçen kimlikleriyle (Washington and Karen, 2001) farklı sosyal statülere mensup bireylerin bir araya geldiği bir sosyal gurup olduğu düşünüldüğünde, farklı statüdeki bireylerin gündelik yaşamda kendilerinden beklenmedik davranışları spor alanlarında rahat bir şekilde ortaya koymaları söz konusudur.

Sporda ekonomik şiddet olgusu, fiziksel şiddet ve psikolojik şiddet türlerine göre görünürlügü düşük olmasına rağmen, etki alanı belirtilen şiddet türlerinden daha fazladır. Ekonomik şiddetin toplumsal yapı içerisinde anlamlandırması kolay değildir. $\mathrm{Bu}$ durum ister istemez spor alanlarını da kapsamaktadır. Spor kurumuna dışardan bakıldığında toplumsal algı olarak elit sporcuların çok yüksek ekonomik gelire sahip oldukları düşüncesi egemendir. Bütün spor branşları için bu tür bir genelleme yapılması bilimsel olarak söz konusu değilken, elit manada daha çok kitlesel yaygınlığı olan (örneğin 
futbol) ve kendi içerisinde en üst kategoride yer alan sporlarda bir nebze bu durumdan söz edilebilir. Alt kategorilerde bu düşünceyi desteklemek realist bir bakış açısı sunmamaktadır.

Sporu elit spor seviyesinde yapan sporcuların ekonomik anlamda ihtiyaçlarını spor kurumundan karşılamaları söz konusudur. Sporda ekonomik sınırlılık/yoksunluk yaşanması ekonomik şiddet olarak ortaya çıkarken, sporda ekonomik şiddete maruz kalan sporcuların iyi bir performans sergilemesi zorlaşmaktadır. Araştırmaya katılan farklı bireysel ve takım sporlarıyla uğraşan sporcuların birçoğu emeğinin ekonomik karşılığını yeterince alamadığını belirtmektedir. Cinsiyet farkı gözetmeksizin sporcuların söylemlerinde, genel olarak K10 kodlu örneklemin şu söyleminde olduğu gibi "Aynı performansta olan sporculara kulüp içerisinde farkl maaşlar verilmesi bizi oldukça olumsuz etkilemiştir. " eşit ücret dağılımı olmadığ1, E3 kodlu örneklemin "Eski tekne ve yelkenle yarışırdım. Rakiplerimiz her yarış yeni tekne ve yelken alacak güçteydiler. O yüzden birkaç sene çok zorluk çektim. Ben olimpiyat sporcusu olarak halen daha bu sorunları fazlasıyla yaşıyorum. Ekonomik ve teknik yetersizliklerle nasıl ülkeme altın madalya getirebilirim ki" ifadesinde belirttiği gibi ekipman yönünden rakiplerle aynı nitelikte olmadıklarını, E2 kodlu örneklemin "Bizim branşlarımızda sponsorlar önemlidir. Antrenörlerin bir maç için sponsor bulup o geliri sporculara yansıtmadan kendi bütçesine koyduğuna çok şahit oldum" söyleminde belirttiği gibi antrenörlerin çoğunlukla sporcuları sömürdüklerini, sporculara verilen prim ya da sponsorluk gelirlerinin tasarruf hakkının antrenörlerde olduğunu ve bu paralara genellikle antrenörler tarafından el konulduğunu, E9 kodlu örneklemin "Ligde oynuyoruz. Bir sezon boyunca yöneticilerin ve antrenörlerin sözde vaatlerini dinliyoruz. Ama halen tam anlamıyla vaatler yerine gelmiş değil, gelmiyordu. Genelde çok cüzi miktar kazaniyoruz" söylemindeki gibi verilen vaatlerin yerine getirilmediğini sporcular benzer ifadelerinde ortaya koymuşlardır. Bu açıdan sporda ekonomik şiddet gurup içi dinamikleri temelden yıkan, sporcunun motivasyon ve performansını derinden etkileyen ve diğer şiddet türlerini arka planda destekleyen bir şiddet türü olarak karşımıza çıkmaktadır.

Araştırma sonuçlarında elde edilen bir diğer şiddet türü de cinsel şiddettir. Sporda cinsel şiddet yine seyirci, antrenör, sporcu bağlamında ele alınması gereken çok yönlü ve boyutlu bir konudur. Diğer şiddet türlerine oranla bilimsel olarak üzerine daha az çalışılan, görünürlüğü daha düşük seviyede olan ve sporcunun spor ve sosyal hayatını direkt olumsuz etkileyen şiddet türüdür. Araştırmaya katılan sporculardan sadece E8 kodlu örneklem sporda cinsel şiddetin olmadığını belirtmiş, diğer örneklemlerin hepsi farklı boyutlarıyla cinsel şiddetin olduğunu ve bu şiddet türünün çok fazla gün yüzüne çıkmadığını ifade etmişlerdir. Antrenör tarafından cinsel şiddete maruz kalma olgusu daha çok temas gerektiren bireysel spor dallarında ve antrenmanlarda gözlendiğini K12 kodlu örneklemin "Judoda yer newzoosu dediğimiz bir çalışma var yakın temasta bulunuyorsun. Erkeklerle çalışmamıza salon içinde izin verilmiyordu. Fakat hoca teknikleri göstermek için bizimle yerde teknik çalışması yapıyordu. Bir antrenörüm vardı teknikleri gösterirken dokunuşundan anlyyor insan, ister istemez de rahatsız edici bir dokunuş olduğunu. Diğer bir erkek hocamda bunu hissetmiyordum. Hoca nasil temasta bulunduğuna dikkat ediyordu. Olması gerektiği gibi, çok yakın değil uzaktan ve elinin tersiyle anlatmak istediğini anlatıyordu, diğere böyle değildi" söyleminden hareketle somutlaştırmak mümkündür.

Yine cinsel şiddetin farklı bir boyutu olarak karşımıza çıkan seyirci şiddetiyle sporcuların çok fazla karşılaşmaları söz konusudur. Seyirci tarafindan sporcunun, bir cinsel obje olarak görülmesi, gözle ya da sözle taciz edilmesi söz konusudur. Diğer örneklemlerle benzer ifadeleri kullanan K4 kodlu örneklemin "Voleybol müsabakalarında giyilmesi gereken klyafetler sabit ve zorunludur. Kısa tayt olması genelde müsabakalarda tayt muhabbeti yüzünden sporcunun seyirciler tarafindan cinsel bölgelerine bakışı altında kalması veya laf atılarak iğrenç cümleler kullanılmasıyla çok karşılaştım ve şahit oldum, bazı insanlar maç izlemek için gelmiyor. Sporcuları göz baskısı altında tutuyorlar." söylemleri seyirci tarafından sporcunun maruz kaldığı cinsel şiddeti özetlemektedir.

Son söz olarak, sporda şiddet olgusu üzerine düşünüldüğünde genellikle fiziksel ve psikolojik şiddet ilk akla gelmektedir. Sporda ekonomik ve cinsel şiddet çok fazla çalışılmayan ve çalışılması gereken alanlar olarak karşımıza çıkmaktadır. Araştırma sonuçları bize göstermektedir ki, ekonomik ve cinsel şiddet diğer şiddet türleri kadar spor alanlarında yaygındır ve yıkıcı etkileri daha yüksektir. Spor kültürü ve olimpik ruhun gelişmesi için sporda şiddet olgusu bütüncül yaklaşımlarla ele alınarak azaltılması için çözüm önerileri sunulmalıdır. Unutulmaması gereken bir diğer hususta bu şiddet türleri birbirini etkileyen ve birbirlerini doğuran şiddetlerdir. 


\section{KAYNAKÇA}

Akkaş, İ. ve Uyanık, Z. (2016). Kadına Yönelik Şiddet, Nevşehir Hacı Bektaş Veli Üniversitesi SBE Dergisi, 6(1):32-42.

Aktaş, A.M. (2006). Aile içi şiddet. Ankara: Elma Yayınları.

Arendt, H. (2016). Şiddet Üzerine, Çev. Bülent Peker, 8. Baskı, İstanbul: İletişim Yayınları.

Ayan, S. (2007). Aile İçinde Çocuğa Yönelik Şiddet (Sivas İlköğretim ikinci kademe öğrencileri üzerine bir inceleme). Yayımlanmamış doktora tezi, Sivas: Cumhuriyet Üniversitesi Sosyal Bilimler Enstitüsü.

Aydın, Ş.ve Özkul, E. (2007). İşyerinde Yaşanan Psikolojik Şiddetin Yapısı ve Boyutları: 4- 5 Yıldızlı Otel İşletmeleri Örneği. Anadolu Üniversitesi Sosyal Bilimler Dergisi. 7(2): 169- 186.

Bandura, A. and Walters, R.H. (1978). Social Learning Theory, Journal of Communication, 28(3): 1229

Bandura, A. (1982). Self-efficacy Mechanism in Human Agency. American Psychologist, 37(2), 122.

Bauman, Z. (2011). Bireyselleşmiş Toplum, Çev. Yavuz Alogan, 2. Basım, İstanbul: Ayrıntı Yayınları.

Braun, V. ve Clarke, V. (2006). Using Thematic Analysis in Psychology. Qualitative Research in Psychology, 3(2): 77-101.

Dumitriu, L. D. (2012), The Community Behind Sport Competition, Redefining International Conference RCIC12: Community in Intercultural Context, Brasov, 14-16 June 2012, p:30-36.

Dunning. E., Murphy, P. \& Williams, J. (1991). Spectator violence at football matches: towards a sociological explanation. Brit J Sociol, 37(2), 221-244.

Elias, N. (1976). Sport et violence, Actes de la Recherche en Sciences Sociales, 2(6): 2-21

Freedman, J. L. (2002) Media Violence and its effect on Aggression: Assessing the Scientific Evidence, Toronto, University of Toronoto. Key Canadian academic that presents cogent critique of Anderson's work.

Fromm, E. (1981). Freud Düşüncesinin Büyüklügü ve Sınırları, (Çev. A. Artan), İstanbul: Dilek Matbaas1,

Hogg, A.M. and Vaughan, M.G. (2011). Sosyal Psikoloji, 2. Baskı, (Çev. İbrahim Yıldız ve Aydın Gelmez), Ankara: Ütopya Yayınları,

Jarvie G. (2005). Introduction: Sport, Racism and Ethnicity. In: Sport, Racism and Ethnicity. Ed: Jarvie G, Taylor and Francis e-Library.

Jarvie, G. (2012). Sport, violence and crime, Routledge Online Studies on the Olympic and Paralympic Games(in), 1.42, 199-216, DOI: 10.4324/9780203970003_chapter_9.

Kılıç, G. (2017). Kadın Akademisyenlerin Kadına Yönelik Ekonomik Şiddet Algısı: Düzce Üniversitesi Örneği, Yayınlanmamış Yüksek lisans Tezi, Sivas: Cumhuriyet Üniversitesi Sosyal Bilimler Enstitüsü.

Kılıç, M. (2013). Tek Partili Dönemde Türkiye'de Modern Sporun Teşekkülü, Tarih Okulu Dergisi, 14(1):27-53.

Kılıç, M. (2014). Gençliğin Şiddet Algısı: Düzce İli Örneği. A. Ertuğrul (Ed.), Düzce'de Tarih ve Kültür. (ss.216-224), Bursa: Gaye Kitabevi.

Kılıç, M. (2015a). Türkiye'de Etnisite Bağlamında Taraftar Üzerinde Spor Medyasının Etkisi, Uluslararası Sosyal Araştırmalar Dergisi, 8(36): 663-673. 
Kılıç, M. (2015b). Dramaturjik Teori Ekseninde Spor, Sosyoloji Araştırmaları Dergisi, 18(1):126-157.

Kılıç, M. (2016). Gençlik Şiddet ve Serbest Zaman, İstanbul: Doğu Kütüphanesi Yayınları.

Kılıç, M. ve Aslan, M. (2016). Sovyet Toplumunda Sporun Rolü, Tarih Okulu Dergisi, 9(25): 195-213.

Kılıç, M. ve Arslan, A. (2018). Parçalanmış Aileye Mensup Lise Öğrencilerinin Sosyalleşmesinde Sporun Etkisi, Elektronik Sosyal Bilimler Dergisi, 17(66): 505-517.

Kılıç, M. (2018). Etnisite ve Spor, 2. Baskı, Konya: Eğitim Yayınları.

Kocacık, F. (2001). Şiddet Olgusu Üzerine, C.Ü. İktisadi ve İdari Bilimler Dergisi, 2 (1), 1-7.

Kocadaş, B. ve Kılıç, M. (2012). "Düşük Sosyo-Ekonomik Yapıdaki Kadın ve Çocuğun Şiddet Algısı”, Uluslararası Katılımlı Kadına ve Çocuğa Karşı Şiddet Sempozyumu, Ankara: Mutlu Çocuklar Derneği Yayınları.

Malmisur, M. C., and Schempp, P. G. (2004), "SportParticipation: its influences on Juvenile Delinquency",International Journal of Physical Education, 21(3):1-5.

Öğülmüş, S. (2006). Okullarda şiddet ve alınabilecek önlemler. Eğitime Bakış, 2(7), 16-24.

Robins, D. (1990), Sport as Prevention: The Role of Sport in Crime Prevention Programmes Aimed at Young People, (University of Oxford, Centre for Criminological Research occasional paper no. 12) Oxford: The Centre

Rudd, A. (2005). Which "Character" Should Sport Develop?, Physical Educator, 62(4):205-211).

Tekin, U. ve Kılıç, M. (2010). Gelişmiş Ülkelerde ve Türkiye'de Okullarda Güvenli Ortamın Sağlanması, Uluslararası Risk Altındaki ve Korunması Gereken Çocuklar Sempozyumu:2, s.111-129, Ankara.

Tosyal1, F. (2018). A Brief Review on the Effects of Violent Media on Youths, Muhakeme Dergisi, $1(2): 85-93$.

Ünsal, A. (1996). “Genişletilmiş Bir Şiddet Tipolojisi”, Cogito. Sayı 6-7. Kış-Bahar. s.29-36.

Washington, E.R. and Karen, D. (2001). Sport and Society, Annual Review of Sociology, 27: 187-212. https://www.haberler.com/gana-da-hakem-theresa-bremensu-yu-saha-ortasinda-11941710-haberi/ 